\title{
Peran Kiai Dalam Perlindungan Sosial (Studi Kegiatan Yatiman Di Pondok Pesantren Al- Kholily Ma’unah Sari Pilang Sampung Ponorogo)
}

\author{
Binti Masruroh \\ Institut Agama Islam Sunan Giri Ponorogo \\ bintimasruroh@gmail.com \\ Syamsul Wathoni \\ Institut Agama Islam Sunan Giri Ponorogo \\ tonyahmed28@gmail.com
}

\begin{abstract}
Abstrak
Kegiatan yatiman di Pondok Pesantren Al-Kholily Ma'unah Sari dilaksanakan setiap tangal 10 muharram. Yang langsung di pimpin oleh seorang kiai, Kiai adalah orang yang mengajarkan pengetahuan agama dengan cara berceramah, menyampaikan fatwa agam kepada masyarakat luas. Kiai secara etimologis (lughotan) menurut adaby darba kata kiyai berasal dari bahasa jawa kuno "kiya-kiya" yang artinya orang yang dihormati. Selain itu ada pula yang mengartikan man balagha sinnal arbain, yaitu orang-orang yang sudah tua umumya atau orang-orang yang mempunyai kelebihan. Sedangkan secara terminology Kiai menurut Manfred Ziemek adalah pendiri dan pemimpin sebuah pesantren yang sebagai muslim terpelajar, telah membaktikan hidupnya demi Allah serta menyebarluaskan dan mendalami ajaran-ajaran, padangan Islam melalui kegiatan pendidikan Islam. Kiai Pondok Pesantren Al-Kholily Ma'unah Sari yang bernama Kiai Agus Mahmud Isa Mudzofar selain pandai ilmu beliau juga dikenal arif dan karismatik, berkat kearifan dan karismatik beliau mampu menarik para donator-donatur yatiman.
\end{abstract}

Kata Kunci: Kiai, Pondok Pesantren, Yatim.

Abstract

Compensation activities at the Al-Kholily Ma'unah Sari Islamic Boarding School are held every 10 muharrams. Directly led by a kiai, Kiai is a person who teaches religious knowledge by giving lectures, conveying religious fatwas to the wider community. Etymologically kiai (lughotan) according to adaby darba the word kiyai comes from the ancient Javanese language "kiya-kiya" which means people who are respected. In addition, there are also those who interpret man balagha sinnal arbain, namely people who are generally old or people who have advantages. Meanwhile, in terms of Kiai, according to Manfred Ziemek, he is the founder and leader of an Islamic boarding school who, as an educated Muslim, has dedicated his life to Allah and disseminates and deepens the teachings of Islam through Islamic education activities. The Kiai of Al-Kholily Ma'unah Sari Islamic Boarding School named Kiai Agus Mahmud Isa Mudzofar, apart from being good at knowledge, is also known as wise and charismatic, thanks to his wisdom and charismatic ability to attract Yatiman donors.

Keywords: Kiai, Islamic Boarding School, Orphans. 


\section{Pendahuluan}

Di era globalisasi seperti sekarang ini dengan pesatnya perkembangan ilmu teknologi, manusia dituntut untuk mengikuti perkembangan zaman tersebut. Sebagian manusia tidak memiliki kemampuan untuk mengikuti perkembangan tersebut sehinggaakan menyebabkan tingkat pengangguran dan kemiskinan di Negara ini semakin meningkat. Hal ini disebabkan karena kurangnya lapangan kerja bagi manusia yang kurang ahli dalam mengikuti perkembangan zaman yang seperti sekarang ini.

Akibat dari timbulnya pengangguran dan kemiskinan di suatu Negara akan menyebabkan banyaknya manusia yang turun ke jalan-jalan untuk mencari uang dengan cara meminta sedikit belas kasihan kepada pengendara di jalan tersebut (tidak mempunyai pekerjaan) yang biasa disebut dengan orang-orang fakir miskin. Di suatu jalan-jalan juga terdapat beberapa anak-anak kecil yang terlantar atau ikut serta dalam mencari uang untuk mempertahankan hidup karena mereka sudah tidak memiliki ayah atau ibu yang biasa disebut dengan anak yatim, piatu, atau dhuafa (Wikipedia).

Menghadapi era globalisasi dan informasi, pesantren dalam kapasitasnya sebagai lembaga pendidikan Islam yang memiliki akar tradisi yang kuat di masyarakat cukup menarik untuk kita cermati kembali.Dalam perspektif Islam, pendidikan memainkan peranan yang sangat penting dalam meningkatkan sumber daya manusia dan menunjang tugasnya sebagai khalifah di muka bumi.Merupakan ranahnya pesantren dalam memperbaiki akhlak dan perkembangan ilmu keagamaan terhadap seluruh santri sebagai peserta didik yang mengenyam pendidikan di pesantren. Untuk itu, dalam perannya pesantren harus mampu berkembang dari berbagai aspek guna mewadai segala hal yang menjadi kebutuhan para santrinya pada era dimanateknologi dan ilmu pengetahuanmengalami perkembangan pesat. Berbagai cara dilakukan oleh pesantren dalam menghadapi era modern ini, salah satunya konsep modernisasi pada pondok pesantren. Modernisasi pendidikan Islam merupakan suatu konsep yang penuh perubahan. Dilihat dari perspektif perubahan dan perkembangan kebudayaan, kelembagaan pendidikan Islam sulit untuk survivetanpa modernisasi.2Arus globalisasi tidak hanya berdampak pada sosial, politik, dan ekonomi saja tetapi berdampak juga pada dunia pendidikan.Kemajuan di bidang teknologi transformasi merupakan salah satu produk yang diunggulkan dalam arus global serta bentuk modernisasi teknologi, dan juga berpengaruh langsung pada pendidikan.Akan tetapi pengaruh ini bisa dalam bentuk negatif maupun bentuk positif.3Peran pesantren dalam mengajarkan, mengarahkan, membimbing para santri dalam proses pendidikan keagamaan 
menjadi penentu bagaimana santri secara keseluruhan mampu membedakan berbagai hal negatif maupun positif serta cara menyikapi beberapa hal sebagai produk dari modernisasi era global (Tyastuti, 2018)

Dari fenomena di atas ada beberapa organisasi yang turun tangan untuk meminimalisir tingkat kemiskinan dan pengangguran di Negara ini dengan adanya bantuan dari para dermawan. Organisasi-organisasi yang bermunculan untuk meminimalisir kemiskinan dan pengangguran adalah himpunan mahasiswa islam, pondok pesantren, panti asuhan, atau panti jompo.

Salah satu dari organisasi yang dimaksud adalah Pondok Pesantren Al-Kholily Ma'unah Sari Pilang Tulung Sampung Ponorogo. Pondok Pesantren Al-Kholily Ma'unah Sari atau yang biasa disebut dengan Pondok Pesantren Al-Kholily Ma'unah Sari yang berada di bawah naungan Kementrian Agama. Pondok Pesantren Al-Kholily Ma'unah Sari adalah suatu lembaga pendidikan dan keagamaan yang bertujuan untuk melestarikan, mengajarkan dan melestarikan ajaran islam kepada para santri untuk siap menjalani suatu kehidupan dan hidup mandiri. Di dalam Pondok Pesantren Al-Kholily Ma'unah Sari terdapat beberapa kegiatan belajar mengajar, mengaji kitab, diniyah, Taman Pendidikan Al-Qur'an (TPQ), Khotmil Qur'an, Ijazahan, Manaqib, dan juga Kegiatan Santunan Anak Yatim, Piatu, dan Dhuafa.

Salah satu kegiatan rutin yang dilaksanakan di Pondok Pesantren Al-Kholily Ma'unah Sari yaitu Santunan Yatim, Piatu, dan Dhuafa. Kegiatan tersebut bertujuan untuk membantu sebagian masyarakat yatim, piatu, dan dhuafa di sekitar lingkungan pondok dengan bantuan para dermawan yang bersedia untuk menyisihkan sebagian hartanya untuk suatu kebaikan. Pondok Pesantren AlKholily Ma'unah Sari melaksanakan kegiatan Santunan tersebut setiap tanggal 10 Muharram. Bulan Muharram merupakan bulan penentuan awal bagi pertanggalan hijriah. Di bulan Muharram kita umat muslim dilarang untuk melakukan peperangan atau berbuat kerusakan didalamnya AlQuran surat At-Taubah ayat: 36 Allah berfirman:

$$
\begin{aligned}
& \text { ان عدة الثهور عند الله اثنا عشر شهرا في كتب الله خلق في السموت والارض منها اربعة حرم ذللك الدين القيم فلا } \\
& \text { تظلمو ا فهين انفسكم وقاتلو ا المشركين كافة كمايقاتلونكم كافة واعلمو ا ان اله مع المتقين }
\end{aligned}
$$

Artinya: "Sesunguhnya bilangan bulan pada sisi Allah ialah dua belas bulan, dalam ketetapan Allah di waktu Dia menciptakan langit dan bumi, diantaranya empat sesunguhnya bilangan bulan disisi Allah ialah dua belas bulan, dalam ketetapan Alah di waktu Dia menciptakan langit dan bumi, di antaranya empat bulan haram. Itulah (ketetapan) agama yang lurus, maka janganlah kamu menganiaya diri kamu dalam empat bulan itu, dan perangilah 
kaum musyrikin itu semua sebagaimana merekapun memerangi kau semuanya; dan ketauilah bawasanya Allah beserta orang-orang bertakwa (at-Taubah: 36).

Diterangkan dalam tafsir al-mishbah jilid 5 halaman 554-555 bahwa ayat ini membahas tentang kaum musyrikin yang sering menambah atau memutar balikan bilangan bulan dalam satu tahun. Disini Allah SWT berfirman menjelaskan bahwa sesunguhnya batas yang tidak dapat ditambah atau dikurangi menyangkut bilangan bulan disi Allah SWT yakni menurut perhitungan perhitungan dan ketentuan-nya adalah dua belas bulan tidak berlebih dan berkurang, dan tidak dapat diputar balikan tempatnya. Bilangan itu berada, ketetapan Allah SWT sejak dahulu diwaktu dia pertama kali menciptakan langit dan bumi yang atas keberadaanya waktu tercipta. Dua belas bulan itu diantaranya terdapat empat bulan tertentu, bukan sekedar bilangan empat dalam setahun. Keempat yang tertentu itu adalah haram yakni agung. Itulah ketetapan agama yang lurus, maka jaganlah kamu menganiyaya diri kamu dalamnya yakni dalam keempat bulan haram itu dengan berbagai dosa apapun dan terhadap siapapun, antaranya lain dengan menambah atau mengurangi bulan (Shihab, 1996).

Nabi sendiri menyebutkan ada empat bulan yang dimuliyakan, di dalam hadist yang diriwayatkan oleh Imam Bukhori:

$$
\begin{aligned}
& \text { حدثنا عبد الله ابن عبد الوهاب حماد بن زيد عن أيوب عن محمد عن ابن ابى بكرة عن ابى بكرة عن النبى صلى الله عليه }
\end{aligned}
$$

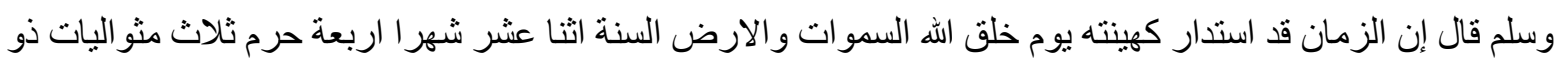

$$
\begin{aligned}
& \text { القعدة وذو الحجة والمحرم ورجب مصر الذى بين جمادى وسعبان }
\end{aligned}
$$

Artinya: Telah menceritakan pada kami Abdhullah bin Abdhul wahhab telah menceritan kepada kami Hammad bin Zaid dari Ayyub dari Muhammad dari ibnu Abu Bakrah dari Abu Bakharah dari Nabi Muhammad Shallallahu 'alahi wassalam bersabda: "sesunguhnya waktu telah berputar sebagaimana hal itu ditetapkan pada hari Allah menciptakan langit dan bumi. Dalam setahun ada dua belas bulan, diantaranya ada empat bulan yang mulia. Tiga darinya berturut-turut, yaitu Dzul Qa'dah, Dzul Hijjah, Muharram, dan Rajab yang bisa diagungkan Bani Mudlar yaitu antara Jumadil tsani dan Sya'ban.

Berdasarkan keterangan diatas maka empat bulan yang dimulyakan umat muslim dilarang untuk berbuat kerusakan ataupun berbuat maksiat, akan tetapi lebih diajarkan untuk memperbanyak melakukan perbuatan amaliah-amaliah yang baik semata-mata hanya untuk mengharap ridho Allah SWT. Ada sekali keistemewaan yang terkandung pada bulan Muharram ini, salah satunya dengan cara menyantuni anak yatim, fakir miskin, dan para janda miskin 
Dalam pelaksanaannya juga selalu diadakan tradisi usapan anak yatim piatu atau fakir miskin di lingkungan sekitar. Pelaksanaan Santunan tersebut dilaksanakan pada bulan Muharram karena pada bulan tersebut disunnahkan bagi kita untuk memperbanyak melakukan kebaikan.

\section{Metodologi penelitian}

Dalam suatu penelitian diperlukan adanya suatu metode yang digunakan untuk menyelesaikan suatu laporan penelitian yang dilakukan. Dalam penelitian ini metode-metode yang digunakan adalah sebagai berikut: penelitian ini pendekatan yang dilakukan adalah melalui pendekatan Sosiologi kualitatif. Arti pendeketan kualitatif adalah data yang dikumpulkan bukan berupa angka-angka, melainkan data tersebut dari naskah wawancara. Krik dan Miller memberikan pengertian penelitian kualitatif sebagai tradisi penelitian yang tergantung pada pengamatan sesuai dengan orang-orang di sekitar objek dalam bahasa dan peristilahan sendiri (Moleong, 2009).

Penelitian ini dilaksanakan dengan menggunakan metode kualitatif yang berarti metode yang digunakan untuk meneliti kondisi objek yang alamiah, dimana peneliti sebagai instrumen kunci, teknik pengumpulan data dilakukan secara gabungan, analisis data bersifat induktif, dan hasil penelitian kualitatif dan lebih menekankan pada generalisasi. Sebagaimanatelah dikemukakan oleh Fatimah Djajasudarma mengenai metode kualitatif, metode ini merupakan prosedur yang menghasilkan data deskriptif berupa data tertulis atau lisan dari suatu masyarakat. Penelitian ini bersifat deskriptif, yakni menjelaskan atau mengungkapkan suatu masalah dan keadaan sebagaimana adanya (Djajasudarma, 2006).

\section{Hasil Penelitian dan Pembahasan}

Pondok Pesantren Al-Khaolily Ma'unah Sari berdiri tahun 1970, dimana dulu didirikan oleh seorang Kiai yang bernama Kiai Asrofi. Beliau satu-satunya putra dari Kiai Muhamad Ikrom, beliau dikenal sebagai sosok Kiai suka riyadoh sehingga beliau mempuyai akal di luar manusia. Kiai Asrofi mencari ilmu pada usia 13 tahun mondok dipesantren jeresan. Diman pada saat itu dipimpin oleh Kiai H. Hasbulloh selang beberapa tahun beliau diangkat sebagai lurah pondok. Beliau dikenal sebab kecerdasanya dan kebijaksanaanya sehingga beliau dikenal sebagai orang yang mampu, selang beberapa tahun beliau pulang kembali kerumah lalu menikah dengan seorang gadis yang bernama Siti Mariyam dari desa Dasun. Dari perkawinan beliau dikaruniai tiga putri dan satu putra, dengan kecerdasan dan kearifan beliau. Ada seorang santri dari Jeresan yang mengikuti beliau untuk tolabul ilmu, sehingga semakin lama santrinya bertambah banyak dan beliau berinisiatif untuk mendirikan pondok, Saat itu pondoknya bernama Miftahul Ulum dan mengkaji 
kitab-kitab kuning dan beliau terkenal dengan mengembleng banser-banser dan angkatan pada saat itu. Pondok Pesantren Al-Miftah dengan seiring zaman pondok tidak berkembang dan beliau semakin tua pada akirnya meningal dunia. PP Al-Miftah mulai diteruskan oleh putranya Kiai Agus Mahmud Isa Mudzofar beserta istrinya, akirnnya Pondok Pesantren mengalami kemajuan dan diganti nama Pondok Pesantren Al-kholily Ma’unah Sari pada tahun 2004.

Nama Pondok Pesantren Al-Kholily diambil dari nama guru besar beliau bernama Seh Jauhari Umar, yang member ijazah sholawat jawahirul bahriyah dari Kiai Kholil Bangkalan. Jadilah Al-Kholily dan Ma'unah Sari dari nama pondok istri beliau, pondok al-quran Ma'unah Sari Bantar Kidul Kediri untuk tafa'ulan mengharap barokah dari guru-guru beliau. Sehingga berdirilah Pondok Pesantren Al-kholily Ma'unah Sari yang baru, dan sekarang sudah memiliki 7 lembaga yang dinaunginya. Dimana ini dimulai dirintis putra beliau Kiai Agus Mahmud Isa Mudzofar dan Ibu Yai Binti Masruro. Inilah sedikit cuplikan sejarah PP Al-Kholily Ma’unah Sari.

Kegiatan yatiman di Pondok Pesantren Al-Kholily Ma'unah Sari dilaksanakan setiap setahun sekali pada tahu 10 muharram, sebelum dua hari acara yatiman para pengurus sudah sibuk mempersiapkan apapu kebutuhan untuk kegiatan yatiman. pengurus selalu berusaha agar acara yatiman di Pondok Pesantren Al-Kholily Ma'unah Sari berjalan dengan lancar maka dilaksanakan gladibersih dan mendekorasi tempat yatiman pagi sebelum acara yatiman dimulai dari penyingkronan tugas masing-masing agar tidak terjadi kesalahan dalam acara yatiman natinya. Acara yatiman di mulai jam 13.00 WIB pengurus menata tempatnya masing-masing seperti tempat parkir, tempat senek, tempat penerimaan dana donatur. Jam 13.30 WIB pengurus menyambut kedatangan anak yatim dan mempersilahkan mereka ketempat yang sudah di siapkan oleh pengurus untuk tempat istrahaat anak yatim sebelum acara yatiman dimulai. 14.00 WIB para santri-santri Pondok Pesantren Al-Kholily Ma'unah Sari melantunkan sholawat-sholawat nabi untuk menunggu kedatangan para undangan yatiman, ketika undangan sudah datang sebelum acara yatiman di mulai ada pembacaan manakib Seh Abdhul Khodir Al-Jailani, karena jawahirul ma'ani begitu besar pengaruhnya seperti mempermudah rezeki, membahagiakan keluarga, dan menenangkan hati.

Kiai Agus Mahmud Isa Muhdofar mendapatkan ijazah manakib dari guru beliau KH. Ahmad Jauhari Umar Pondok pesantren Darusalam Tegal Rejo Pasuruhan, ketika itu Kiai Agus Mahmud Isa Muhdofar mondok selama tiga tahun beliau belajar riadoh puasa 40 hari, setelah itu 100 hari, 1 tahun sampailah 17 taahun. Berkat riadhoh beliau dan taat dawoh guru-guru beliau pada saat pertama kali Kiai Agus Mahmud Isa Muhdofar memimpin pondok santrinya hanya 2, berkat istiqomah beliau sekarang santri pondok pesantren Al-Kholily Ma’unah Sari menjadi 150 santri. 
Manakib adalah adalah cerita kehidupan kekasih Allah SWT, ketika hidup beliau Seh Abdul Qodir Jailani menghadapi berbagai tantangan, daan musibah. Semua tidak bisa diselesaikan atau sulit dicarikan jalan keluar karena bigitu banyak masalah yang dihadapi, beliau Seh Abdul Qodir Jailani berdo'a kepada Allah SWT dengan bertawasul atau wasilah di makhomnya beberapa wali Allah SWT (kekasi-kekasih Allah SWT), setelah sampai di bangkalan beliau bermimpi bertemu dengan tiga kekasih Allah SWT beliau bercakap, dan akirnya diberi ijazah manakib oleh Said Abdhullah, Siti Maisaroh, dan Said Sarifudin. Masalah beliau tidak kunjung terselesaikan, setelah beliau mengamalkan manakib akirnya dikit demi sedikit akirnya masalah beliau terselesaikan.

Kiai adalah orang yang mengajarkan pengetahuan agama dengan cara berceramah, menyampaikan fatwa agam kepada masyarakat luas (Sukanto, 1999). Kiai secara etimologis (lughotan) menurut adaby darba kata kiyai berasal dari bahasa jawa kuno "kiya-kiya" yang artinya orang yang dihormati (Raharjo, 1988). Selain itu ada pula yang mengartikan man balagha sinnal arbain, yaitu orang-orang yang sudah tua umumya atau orang-orang yang mempunyai kelebihan.

Sedangkan secara terminology Kiai menurut Manfred Ziemek adalah pendiri dan pemimpin sebuah pesantren yang sebagai muslim terpelajar, telah membaktikan hidupnya demi Allah serta menyebarluaskan dan mendalami ajaran-ajaran, padangan Islam melalui kegiatan pendidikan Islam (Ziemek, 1986).

Secara umum Kiai mempunyai beberapa pengertian yaitu:

1. Kiai adalah orang yang memiliki lembaga pondok pesantren, menguasi pengetahuan agama serta konsisten dalam menjalankan ajaran-ajaran agama.

2. Kiai yang ditunjukan kepada meraka yang mengerti ilmu agama, tanpa memiliki lembaga pondok pesantren atau tidak menetap dan mengajar di pondok pesantren.

3. Kiai adalah orang yang mengajarkan pengetahuan agama dengan cara berceramah, menyampaikan fatwa agama kepada masyarakat luas.

Seorang Kiai mempunyai pengaruh karismatik yang luar biasa, sehingga Kiai tidak disamakan dengan ulama'. Kiai memiliki keunggulan baik secara formal maupun sebagai orang alim, karena pengaruhnya yang dipercaya oleh sebagian publik. Pengaruh Kiai tergantung pada loyalitas komunitas terbatas yang didorong oleh perasaan hutang budi, namun sepenuhnya ditentukan oleh kualitas kekharismaan mereka (Khosi, 1987).

Secara esensial kata Kiai dan alim memiliki makna yang sama, yakni mereka yang menguasi ilmu agama dan sangat dihormati oleh para santri. Dalam bahasa Jawa. Kiai biasa digunakan dalam 
gelar-gelar yang berbeda yaitu; pertama gelar kehormatan yang biasanya digunaka pada bendabenda yang diangap memiliki kekuatan lain atau biasa benda keramat. Kedua, adalah gelar kehormatan bagi orang-orang yang sudah tua, ketiga gelar Kiai diberikan pada seseorang yang alim pengetahuan Islam atau pemimpin pondok pesantren Dhofier, 1998).

Benda-benda yang diangap memiliki kekuatan lain atau biasa disebut benda keramat, kudua, adalah gelar kehormatan bagi orang-orang yang sudah tua, ketiga gelar Kiai diberikan pada seseorang yang alim (ahli pengetahuan islam) atau pimpimpinan pondok pesantren Fenomena kharismatik menjdi pengaruh dimana posisi Kiai berada. Kiai karismatik bukanlah kenyataan metafisik tetapi sebuah kualitas manusia yang sepenuhnya bisa diamati secara empiric, karena merupakan hal-hal yang berkaitan dengan perbuatan dan sikap manusia.

Beberapa kepribadian yang mungkin bisa untuk mengenali kharismatik Kiai misalnya pengaruh besar, ekpresif, tegas, tekun, pemberani, percaya diri, dan berpandangan tajam dalam ide, karismatik tidak bisa diterjemahkan secara definitif. Dalam tradisi dunia pesantren, ada juga orang yang menjadi Kiai karena ascribed status seseorang menjadi Kiai dikarenakan ayahnya, kakeknya, dari pihak ayah atau ibu semua menjadi Kiai, walau hal ini merupakan penilaian persial (Sobari, 2000). Menurut kamus besar Indonesia, makna kesejahteraan adalah hal atau keadaan sejahtera, keamanan, keselamatan, ketentraman, kemakmuran dan sebagainya (Tim Penyusun, 2004). Sedangkan menurut undang-undang Republik Indonesia Nomer 13 tahun 1998 menyebutkan, kesejahteraan sosial adalah suatu tata kehidupan dan penghidupam sosial baik material maupun sepiritual yang diliputi oleh rasa keselamatan, ketentraman lahir dan batin yang memungkinkan bagi setiap warga Negara untuk mengadakan pemenuhan kebutuhan jasmani, rohani, dan sosial yang sebaik-baiknya bagi diri, keluarga, serta masyarakat dengan menjunjung tinggi hak dan kewajiban asasi manusia sesuai dengan pancasila.

Namun, menurut perserikatan bangsa-bangsa (PBB) kesejahteraan sosial yaitu kegiatankegiatan yang terorganisasi yang bertujuan untuk membantu individu dan masyarakat guna memenuhi kebutuhan-kebutuhan dasarnya dan meningkatkan kesejahteraan selaras dengan kepentingan keluarga dan masyarakat. Dalam hal ini menunjukan kegiatan-kegiatan yang diselengarakan baik oleh lembaga-lembaga pemerintah maupun swasta yang bertujuan untuk mencegah, mengatasi atau memberikan konstribusi terhadap pemecahan masalah sosial, peningkatan kualitas hidup individu, kelompok, dan masyarakat (Suharto, 2005).

Kesejahteraan sosial di Negara-negara maju, disebut dengan jaminan sosial (social security), seperti bantuan sosial (social assistance) dan jaminan sosial (social insurance), yang diselengarakan 
oleh Negara terutama untuk kaum yang kurang beruntung (disadvantaged groups). Sedangkan di Indonesia kesejahteraan Indonesia sering dipandang sebagai tujuan atau kondisi kehidupan yang sejahtera yakni terpenuhinya kebutuhan pokok manusia (Suharto, 2006).

Perkembangan ilmu kesejahteraan sosial tidak bisa dilepaskan dari disiplin pekerjaan sosial, karena ilmu kesejahteraan sosial merupakan perkembangan pemikiran dari disiplin pekerjaan sosial. Akan tetapi, bila pada disiplin pekerjaan sosial (sosial work) pembahasan lebih banyak dipengaruhi oleh disiplin Psikologi dan Sosiologi. Ini dapat dilihat dengan mudah dari hasil bacaan yang ditulis oleh Malcolm Payne (modern sosial work theory). Dalam buku tersebut, pengaruh dari pendekatan Psikologi sangat dominan, kemudian dilengkapi dengan disiplin Sosiologi, yang diikuti dengan perspektif Ekonomi dan Manejemen, Hukum dan Politik terasa lebih kental.

Secara umum tentang peran Kiai Agus Mahmud Isa Mudzofar dalam mengatur lembaga dan sistem yang berlaku di Pondok Pesantren. Membahas peran Kiai, tidak lepas dari kepemimpinan dan manajemen yang diterapkan atau diberlakukan di sebuah lembaga. Baik itu sekolah, ataupun sebuah pondok pesantren. Menghargai puncak kehidupan, dan dia akan senantiasa menziarahi kebenaran (will to truth) dan bukan menziarahi kekuasaan(will to power), agar dia tidak mengalami apa yang disebut split orientation. Yakni, tidak menyatunya antara ucapan dan tindakan.

Sebaiknya seorang Kiai tidak masuk ke ranah politik atau pengurus-pengurus organisasi 'berbau' perbedaan. Beliau, fokus untuk menangani dan mengayomi santri selama 24 jam non stop. Sehingga dengan begitu, seluruh kegiatan santri terkontrol penuh oleh beliu dan bisa membimbing lebih banyak waktu, dari pada sibuk dengan urusan lain di luar pondok pesantren. Dalam kondisi pondok pesantren yang serba terbatas, peran kyai sangat penting. Dalam hal pembinaan terutama, untuk mencapai hasil yang diinginkan, Kiai langsung terjun dan terlibat penuh untuk memantau seluruh kegiatan ekstra (non akademik) di lingkungan pondok pesantren yang dibinanya. Kyai selaku pengasuh, berusaha agar pondok pesantren yang dipimpinnya unggul dalam segala bisang. Beliau adalah pemimpin cerdas dan visioner yang mampu membaca peluang kebutuhan masyarakat ke depan.

Di pondok pesantren Al-Kholily Maunah Sari begitu padat kegiatan-kegiatan para santri, pengasuh pondok pesantren juja mengajarkan para santri-santrinya berda'wah dengan diadakan kegiatan mukhadoroh setiap ahad pon, dan setiap hari jum'at pagi. Pengasuh pondok pesantren AlKholily Maunah Sari juga mengajarkan hukum-hukum kemasyarakatan yang berladaskan atau refensinya diambilkan dari kitab beliau yati kitab fathul khorib, juga mengjarkan nilai-nilai kenegaraan, dan mendidik moral-moral akhlak santri-santrinya. Seperti menghormati orang yang 
lebih tua, ketika ketemu orang lebih tua mencium tanganya, dan berkata-kata sopon. Kiai Agus Mahmud Isa Mudzofar takut kalau para santri-santrinya terjerumus pada zaman sekarang yang begitu minim para pemuda-pemuda tentang nilai-nilai moral, maka beliau menanamkan nilai-nilai moral pada santrinya. Pengasuh pondok pesantren Al-Kholily Maunah Sari juja mengajarkan para santrinya tentang pentingnya jiwa sosial dan mengasihi orang lain dengan diadakanya acara yatiman setiap setahun sekali tanggal 10 muharram, menanamkan jiwa gotong royong sesama santri, dan memberi fatwa-fatwa kepada santrinya apabila menolong orang lain agar tidak bersifat pamrih atau meangharap imbalan, harus berjiwa iklas.

Kiai harus mengarahkan santrinya ke dalam era baru, memerlukan pemahaman yang komprehensif akan dinamika perubahan dan mengelola perubahan itu sendiri. Dari itu, Kyai hendaknya melakukan berbagai upaya untuk meningkatkan prestasi non akademik dalam mewujudkan pondok pesantrennya yang berprestasi yang kompetitif di berbagai bidang, yaitu bidang manajemen, kurikulum, siswa, guru, sarana dan prasarana serta hubungan dengan linkungan / masyarakat sekitar.

Dan pimpinan pondok pesantren Al-Kholily Ma'unah Sari yang bernama Kiai Agus Mahmud Isa Muhdzofar, mengajarkan para santi-santrinya untuk berbuat baik dan sosial dengan mengadakan yatiman yang dilaksanakan setiap tanggal 10 Muharam, beliau mengajarkan tentang keutaman dan kemanfaatan tentang acara yatiman yang kepada santri-santrinya. Kiai Agus Mahmud Isa Mudzofar berperan aktif dan berperan penting dalam kegiatan yatiman di Pondok Pesantren AlKholily Ma'unah Sari. Kiai Agus Mahmud Isa Mudzofar bersama istrinya Binti Masruroh ikut terjun langsung bersama santri-santri dalam kegiatan yatiman untuk mendorong para orang-orang kaya dan masarakat sekitar untuk menyodakohkan sebagian hartanya untuk anak yaim, dan yatim piatu. Dalam kegiatan yatiman Kiai pondok pesantren Al-Kholily Ma'unah Sari memberi maukhidoh hasanah dalam acara yatiman kepada para masarakat, para donatur-donatur, dan para santri-santri tentang bersosial kepada anak-anak yang kurang mampu. Dan mencotohkan tata cara yatiman yang benar yang tidak menyakiti anak-anak yatim.

\section{Kesimpulan}

Berdasarkan peninjauan kajian awal yang telah dilaksanakan dapat disimpulkan sebagai berikut Berdasarkan peran Kiai Agus Mahmud Isa Mudzofar selaku pengasuh pondok pesantren AlKholily Ma'unah Sari. Kiai Agus Mahmud Isa Mudzofar yang berperan penting dalam kegiatan yatiman yang diadakan di pondok pesantren Al-Kholily Ma'unah Sari, karena berkat karismatik dan kearifan beliau mampu mengugah para orang-orang kaya atau masyarakat sekitar untuk 
menyodakohkan sedikit harta mereka kepada anak yatim dan yatim piatu. Bahkan mengajarkan para santrinya untuk berbuat kebaikan dan menanamkan nilai-nilai sosial kepda santri-santrinya dalam ikut peran dalam kegiatan yatiman yang dilaksanakanya setahun sekali setiap bulan Muharam.

Dengan adanya kegiatan yatiman di pondok pesantren Al-Kholily Ma'unah Sari mampu sedikit membantu kesejahteraan para anak-anak yatim dan yatim piatu dalam menyejahterakan. Karena dengan adanya bantuan para donator dan masarakat mampu membuat anak-anak yatim melanjutkan pendidikan dan membuat tidak ada sekat antara si kaya dan miskin. Juga menumbuhkan sikap peduli pada setiap orang tentang pentingnya perlindungan sosial bagi orangorang yang tidak mampu.

\section{Daftar Pustaka}

Dhofier, Zamarkhsyari, (1928). Tradisi Pesantren; Setudi Tentang Pandangan Hidup Kyai, Jakarta: LP3ES.

Djajasudarma, Fatimah,(2006). Metode Linguistik, Bandung: PT Refika Aditama http://id.wikipedia.org/wiki/Yayasan (25 Oktober 2017)

Koshi, Hiroko Hori, (1987). Kyai dan Perubahan Sosial. Jakarta: P3M.

Moleong, Lexy J.(2009), Metode Penelitian Kualitatif, Badung: PT. Remaja Rosda Karya.

Raharjo, M. Dawam, dkk. (1988). Pesantren dan Pembaharuan, Jakarta: LP3ES.

Shihab, Quraish, (1996). Tafsir Al-Mishbah vol 5 Jakarta: Lentera Hati.

Sobari, Moh, (2000) Kyai Nyentrik Merubah Pemerintah, Yogyakarta: LKIS.

Suharto, Edi, (2005). Analisis Kebijakan Publik, Bandung: ALFABETA, 2005

Suharto, Edi, (2006) Membangun Masyarakat Memperdayakan Rakyat Kajian Strategis Pembangunan Kesejahteraan Sosial \& Pekerjaan Sosial, Bandung: Refika Aditama.

Sukanto.(1999). Kepemimpinan Kyai dalam Pesantren, Jakarta: IKAPI.

Tim Penyusun Kamus Pusat Pembinaan \& Pengembangan Bahasa Departemen Pendidikan \& Kebudayaan, (1994). Kamus Besar Bahasa Indonesia, Cet III, ed. II, Jakarta: Balai Pustaka,

Tyastuti, I. (2018). Pesantren Dan Tantangan Modernisasi Dalam Buku Menggerakkan Tradisi Karya Kh. Abdurrahman Wahid. Al-Adabiya: Jurnal Kebudayaan Dan Keagamaan , 13 (02), 348-366. https://doi.org/10.37680/adabiya.v13i02.30

Ziemek, Manfred, (1986). Pesantren dalam Perubahan Sosial, Jakarta: P3M. 1986. 